\title{
Pengaruh Corporate Governance terhadap Kinerja Pasar Emiten yang Terdaftar di Indeks Saham Syariah Indonesia
}

\author{
Rizkary Roslianti \\ Universitas Airlangga \\ e-mail: rizkaroslianti@yahoo.com
}

\begin{abstract}
Corporate governance is one of the important aspects for the company. The application of proper corporate governance will affect the company's value and market performance. This study aims to analyze the effect of corporate governance that represented by institutional ownership, independent commissioner and managerial ownership toward market performance that represented by Tobin's Q. This study used a quantitative approach using secondary data (annual finance report)companies listed on Indeks Saham Syariah Indonesia years 2016-2018. This study used a significance level of 5\%. Based on the regression analysis results, it indicates that institutional ownership and managerial ownership do not have significant effect on Tobin's Q. On the other hand, independent commissioner has significant effect to the Tobin's Q. Simultaneously, institutional ownership, independent commissioner and managerial ownership have significant effect to Tobin's Q.
\end{abstract}

Keywords: corporate governance, market performance, Indonesia sharia stock index

\section{PENDAHULUAN}

Perusahaan yang baik adalah perusahaan yang memperhatikan aspek internal maupun eksternal perusahaan. Faktor internal perlu diperkuat guna menyatukan visi dan misi yang akan dicapai oleh perusahaan. Salah satunya adalah penerapan corporate governance perusahaan untuk meningkatkan nilai perusahaan. Otoritas jasa keuangan menurut CNN Indonesia (2017) menjelaskan bahwa penerapan good corporate governance di Indonesia saat ini masih relatif tertinggal apabila dibandingkan dengan negaranegara yang ada di kawasan ASEAN. Hanya terdapat dua perusahaan Indonesia yang berhasil menembus penghargaan tersebut. Indeks Saham Syariah Indonesia merupakan indeks komposit saham syariah yang tercatat di BEI dan merupakan indikator kinerja pasar saham syariah yang ada di Indonesia. Emiten yang ada di indeks saham syariah ini merupakan seluruh saham syariah yang telah tercantum dalam BEI dan masuk ke dalam Daftar Efek Syariah yang diterbitkan oleh OJK. Dalam kegiatan bisnis yang berbasis syariah sesuai dengan pedoman umum good governance bisnis syariah yang diterbitkan oleh KNKG (2011) bahwa secara operasional bisnis syariah mengacu pada dua asas. Yang pertama adalah ShiFAT (perilaku Nabi dan Rasul dalam beraktivitas) dan yang kedua adalah lima asas umum yang biasanya digunakan sebagai acuan dalam penerapan good governance (transparansi, akuntabilitas, responsibilitas, indepedensi, serta kewajaran dan kesetaraan).

Corporate governance membahas tentang bagaimana memberikan informasi yang sesuai dengan kondisi perusahaan saat ini. Maka dari itu, pentingnya terdapat pengawasan dari internal perusahaan seperti misalnya pentingnya kontribusi dari pihak internal maupun eksternal perusahaan. Pihak eksternal diharapkan dapat meningkatkan pengawasan terhadap kinerja perusahaan dan dapat menyelaraskan kepentingan perusahaan serta investor luar perusahaan. Pihak 
dari eksternal dapat diwujudkan dengan adanya kepemilikan institusional oleh perusahaan lain dan adanya komisaris independen dalam perusahaan, sedangkan pihak internal dapat diwujudkan dengan adanya kepemilikan manajerial. Proses pengawasan yang tepat akan dapat memengaruhi nilai perusahaan yang berdampak pada kinerja pasar.

Penelitian sebelumnya juga melakukan penelitian serupa. Penelitian tersebut menunjukkan hasil yang berbeda-beda. Berdasarkan penelitianpenelitian yang telah dilakukan sebelumnya, peneliti ingin melakukan penelitian tentang pengaruh antara kepemilikan institusional, komisaris independen, dan kepemilikan manajerial dengan kinerja pasar yang diproksikan dengan nilai Tobin's Q.

\subsection{Rumusan Masalah}

Berdasarkan latar belakang, rumusan masalah yang muncul adalah apakah corporate governance dengan variabel kepemilikan institusional, komisaris independen, dan kepemilikan manajerial berpengaruh terhadap kinerja pasar emiten?

\subsection{Tujuan Penelitian}

Penelitian ini bertujuan untuk melakukan analisis apakah terdapat pengaruh yang diberikan oleh corporate governance suatu perusahaan terhadap kinerja pasar perusahaan. Dalam penelitian ini, faktor corporate governance yang digunakan adalah kepemilikan institusional, komisaris independen dan kepemilikan manajerial.

\section{TINJAUAN PUSTAKA}

\subsection{Corporate Governance}

Parkinson (1994) dalam Solomon (2004) menjelaskan bahwa corporate governance adalah proses pengawasan dan control yang dilakukan untuk memastikan bahwa kegiatan manajemen perusahaan sesuai dengan apa yang dikehendaki oleh para shareholder. Penerapan corporate governance yang sesuai dengan pedoman memerlukan beberapa asas yang dianut agar penerapan tersebut berlaku di setiap aspek bisnis dan juga seluruh jajaran yang ada di perusahaan. Berikut asas yang digunakan dalam penerapan corporate governance.

1. Transparansi, yaitu asas yang diterapkan untuk menjaga objektivitas dalam menjalankan bisnis.

2. Akuntabilitas, yaitu asas yang memastikan bahwa perusahaan harus dapat mempertanggungjawabkan kinerjanya secara transparan dan wajar.

3. Responsibilitas, yaitu asas yang memastikan mematuhi peraturan sesuai dengan perundang-undangan serta melaksanakan tanggung jawab terhadap masyarakat serta lingkungan sehingga terpelihara kesinambungan usaha dalam jangka panjang dan mendapat pengakuan sebagai good corporate citizen.

4. Independensi, yaitu asas yang mengharuskan perusahaan untuk dikelola secara independen sehingga masing-masing bagian perusahaan tidak saling mendominasi dan tidak diintervensi oleh pihak lain.

Kewajaran dan kesetaraan. Asas ini berkaitan dengan kepentingan pemegang saham dan pemangku kepentingan lainnya berdasarkan asas kewajaran dan kesetaraan misalnya tanpa membandingkan suku, agama, ras, golongan, gender, atau bahkan kondisi fisiknya.

\subsection{Good Governance Bisnis Syariah}

Bisnis yang berbasis syariah telah berkembang di Indonesia. Hal ini tidak hanya memun- 
culkan aturan-aturan yang berhubungan dengan bisnis syariah saja tetapi juga pedoman yang dapat digunakan sebagai acuan dalam melaksanakan good corporate governance bagi bisnis syariah. Pedoman good corporate governance bisnis syariah ini berlandaskan Al-Qur'an dan Hadist. Berikut asas ShiFAT tersebut.

1. Shiddiq yang artinya adalah benar. Asas ini menunjukkan bahwa bisnis syariah harus menyatakan dan melakukan kebenaran dan kejujuran dalam setiap hal yang dilakukan untuk menghindari adanya penipuan, penggelapan, dan segala bentuk dusta.

2. Fatanah yang artinya cerdas. Asas ini mencerminkan bahwa sebagai pelaku bisnis Syariah harus dapat berpikir secara rasional dalam mengambil segala keputusan agar dapat menetapkan kegiatan yang halal, tayib, ikhsan, dan tawazun.

3. Amanah yang artinya dapat dipercaya. Asas ini menunjukkan bahwa kepercayaan merupakan salah satu kunci dalam menjalankan bisnis syariah. Asas ini diwujudkan dalam bentuk pertanggungjawaban dan akuntabilitas dalam segala kegiatan operasional yang dilakukan.

Tabligh yang artinya menyampaikan. Asas ini menunjukkan bahwa dalam dunia bisnis, segala bentuk penyampaian yang berkaitan dengan kegiatan bisnis syariah dapat dilakukan dalam bentuk sosialisasi praktik bisnis yang baik dan bersih sepertinya yang telah dilakukan oleh Rasulullah saw. dan para sahabatnya.

\subsection{Agency Theory}

Salah satu teori yang ada pada corporate governance ini adalah berhubungan dengan kontrak yang telah dilakukan oleh pemegang saham kepada pihak direksi perusahaan. Teori ini men- jelaskan tentang kontrak yang paling efisien yang dapat memengaruhi hubungan antara pemegang saham dengan direksi perusahaan. Teori ini muncul karena adanya konflik yang biasa terjadi di perusahaan, di mana keinginan dari pihak manajemen perusahaan melakukan tindakan yang sesuai dengan kepentingannya dan dapat mengorbankan kepentingan pemegang saham dalam mendapatkan return perusahaan.

Jensen dan Meckling (1976) menjelaskan bahwa dalam teori keagenan ini memiliki suatu karakteristik hubungan keagenan yang dapat dijelaskan sebagai adanya suatu kontrak yang terjadi antara pihak principal dan mempekerjakan pihak lain (agen) untuk melakukan beberapa pekerjaan yang diinginkan atas nama pihak principal. Pandangan teori keagenan merupakan elemen penting dari mekanisme kontrol untuk memastikan permasalahan yang muncul dari hubungan antara pihak principal dengan pihak agen dapat dikendalikan (Mailin, 2017).

\subsection{Kinerja Pasar}

Kinerja pasar berhubungan dengan nilai perusahaan di pasar modal, salah satunya dengan pengukuran nilai Tobin's Q. Ruan et al., (2011) menjelaskan bahwa nilai Tobin's $Q$ ini dapat merefleksikan nilai perusahaan dan potensi profitabilitas yang dapat dicapai oleh perusahaan di masa yang akan datang.

Nilai Tobin's Q ini merupakan pencerminan antara nilai buku dan nilai pasar ekuitas. Alghifari et al. (2013) menjelaskan bahwa apabila nilai rasio Tobin's Q lebih dari satu maka menunjukkan bahwa investasi asset menghasilkan pendapatan yang memberikan nilai lebih tinggi daripada pengeluaran investasi. Begitu pula sebaliknya. 


\subsection{Pengaruh Kepemilikan Institusional terhadap} Kinerja Pasar

Chung (2009) menjelaskan bahwa kepemilikan institusional adalah bagian dari saham perusahaan yang dipegang oleh investor institusi. Dengan adanya kepemilikan institusional ini diharapkan dapat meningkatkan pengawasan terhadap kinerja dari manajemen perusahaan. Kepemilikan institusional memberikan peran penting dalam hal pengawasan dan pemantauan yang efektif terhadap kinerja perusahaan.

Thanatawee (2014) melakukan penelitian tentang pengaruh antara kepemilikan institusional terhadap Tobin's Q. hasil dari penelitian tersebut menjelaskan bahwa terdapat hubungan signifikan positif antara kepemilikan institusi dengan Tobin's Q. Hasil penelitian berbeda ditunjukkan oleh Erkens, et al. (2012) yang melakukan penelitian tentang pengaruh kepemilikan institusional terhadap kinerja perusahaan. Kepemilikan institusional tidak berpengaruh signifikan terhadap kinerja perusahaan. Berdasarkan argumen tersebut maka hipotesis yang dibentuk adalah sebagai berikut.

$H_{1}$ : Kepemilikan institusional berpengaruh positif terhadap kinerja pasar

\subsection{Pengaruh Komisaris Independen terhadap Kinerja Pasar}

Peraturan tentang Keputusan Ketua Badan Pengawas Pasar Modal dan Lembaga Keuangan Nomor KEP-634/BL/2012, komisaris independen adalah anggota dewan komisaris yang berasal dari luar emiten atau perusahaan publik dan memenuhi syarat yang sudah ditetapkan. Tingkat kepercayaan para investor dengan adanya komisaris independen ini akan berdampak pada peningkatan nilai perusahaan dan kinerja pasar.
Hal ini dikarenakan dengan adanya komisaris independen diharapkan dapat melakukan pengawasan secara lebih intensif sehingga dapat mengurangi munculnya masalah keagenan dalam perusahaan.

Hidayat (2015) melakukan penelitian tentang pengaruh komisaris independen terhadap Tobin's Q. Hasil penelitian tersebut menjelaskan bahwa terdapat pengaruh positif antar variabel tersebut. Berdasarkan argumen tersebut maka hipotesis yang dibentuk adalah sebagai berikut. $\mathrm{H}_{2}$ : Komisaris independen berpengaruh positif terhadap kinerja pasar

\subsection{Pengaruh Kepemilikan Manajerial Terhadap Kinerja Pasar}

Derbali et al. (2017) menjelaskan bahwa kepemilikan manajerial adalah proporsi saham yang dimiliki oleh manajemen. Kepemilikan manajerial dalam suatu perusahaan memiliki peran sebagai pihak yang menyatukan kepentingan manajer perusahaan dengan pemegang saham perusahaan.

Cho (1998), Schmid dan Zimmermann (2007) dan Leung dan Horwitz (2007) melakukan penelitian tentang pengaruh kepemilikan manajerial terhadap kinerja pasar. Hasil penelitian tersebut menunjukkan bahwa terdapat hubungan positif antara kepemilikan manajerial terhadap kinerja pasar. Hasil penelitian berbeda ditunjukkan oleh Jusoh, et al. (2014). Hasil penelitian menunjukkan bahwa kepemilikan manajerial tidak berpengaruh signifikan terhadap nilai Tobin's Q. Berdasarkan argumen tersebut maka hipotesis yang dibentuk adalah sebagai berikut.

$H_{\mathrm{a}}$ : Kepemilikan manajerial berpengaruh positif terhadap kinerja pasar 


\subsection{Kerangka Pemikiran Teoretis}

Penelitian ini menggunakan kerangka pemikiran teoretis yang akan dijadikan acuan dalam melakukan penelitian sehingga penelitian ini menjadi rinci dan terarah. Berikut kerangka pemikiran teoretis yang digunakan.

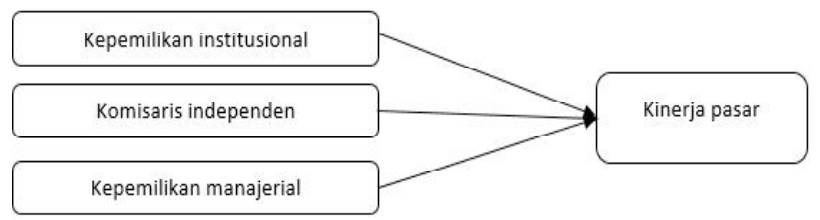

Sumber: diolah penulis

Gambar 2.1 Kerangka Pemikiran Teoretis

\subsection{Metode Penelitian}

Penelitian ini menggunakan pendekatan kuantitatif dengan menggunakan data sekunder yang meliputi dua variabel yang akan diteliti dalam penelitian ini. Kedua variabel tersebut adalah variabel dependen yang diproksikan dengan nilai Tobin's $Q$ dan variabel independen yang diproksikan oleh kepemilikan institusional, komisaris independen dan kepemilikan manajerial.

Pengujian hipotesis pada penelitian ini dilakukan dengan uji $\mathrm{t}$ untuk menguji apakah variabel independen yang digunakan dalam penelitian ini berpengaruh signifikan secara parsial terhadap Tobin's $\mathrm{Q}$ dan uji $\mathrm{F}$ untuk menguji apakah variabel independen yang digunakan dalam penelitian ini berpengaruh secara simultan terhadap Tobin's Q.

Teknik analisis yang digunakan dalam penelitian ini adalah menggunakan analisis regresi linear berganda (multiple linear regression analysis) dengan memanfaatkan data yang telah didapatkan dari penggabungan data cross section (beberapa emiten perusahaan tertentu) dan time series (lingkup waktu tertentu). Berikut adalah model regresi yang digunakan dalam penelitian ini.

$$
Q_{i, t}=\alpha+\beta_{1} K I_{i, t}+\beta_{2} I N D_{i, t}+\beta_{3} K M_{i, t}+e_{i, i}
$$

Di mana:

$\mathrm{Q}=$ Tobin's $\mathrm{Q}$

$\mathrm{KI}=$ Kepemilikan institusional

$\mathrm{IND}=$ Komisaris independen

$\mathrm{KM}=$ Kepemilikan manajerial

$\beta=$ koefisien masing masing variabel independen

$\mathrm{e} \quad=$ Faktor pengganggu di luar model penelitian

\subsection{Populasi dan Sampel}

Populasi yang digunakan dalam penelitian ini merupakan seluruh saham yang terdaftar pada Indeks Saham Syariah Indonesia pada tahun 2016-2018. Sedangkan sampel yang digunakan dalam penelitian ini menggunakan teknik purposive sampling dengan kriteria sebagai berikut.

1. Saham perusahaan tersebut konsisten menjadi emiten indeks saham syariah mulai tahun 2016 hingga 2018.

2. Tidak melakukan stock split dan/atau stock reverse.

3. Emiten memiliki data yang berkaitan dengan kepemilikan institusional, komisaris independen dan kepemilikan manajerial.

\subsection{Definisi Operasional Variabel}

Tabel 2.1 Definisi Operasional Variabel

\begin{tabular}{|l|l|c|}
\hline No & \multicolumn{1}{|c|}{ Xariabel } & Rumus \\
\hline 1. & Kepemilikan Institusional & $\frac{\text { Jumlah saham institusi }}{\text { Jumlah saham beredar }}$. \\
\hline 2. & Komisaris Independen & $\frac{\text { Jumlah komisaris independen }}{\text { Jumlah anggota dewan komisaris }}$. \\
\hline 3. & Kepemilikan Manajerial & $\frac{\text { Jumlah saham manajer, direktur, } \text { komisaris }}{\text { Jumlah saham yang beredar }}$ \\
\hline 4. & Tobin's Q & $\frac{\text { Market value of firm's stock }+ \text { Debt }}{\text { Total assets }}$ \\
\hline
\end{tabular}

Sumber: Hasil olah data 


\section{HASIL DAN PEMBAHASAN}

\subsection{Uji Multikolinearitas}

Tabel 3.1 Uji Multikolnearitas

\begin{tabular}{|c|c|c|c|}
\hline \multirow{2}{*}{ Variabel } & \multicolumn{2}{|c|}{ Collinearity Statistics } & Kesimpulan \\
\cline { 2 - 3 } & Tolerance & VIF & \\
\hline Kep. Institusional & 0,460 & 2,175 & Bebas multikolinearitas \\
Kep. Manajerial & 0,460 & 2,175 & Bebas multikolinearitas \\
Komisaris Ind & 1,000 & 1,000 & Bebas multikolinearitas \\
\hline
\end{tabular}

Sumber: Hasil olah data

Berdasarkan tabel tersebut diketahui bahwa masing-masing variabel independen memiliki nilai $\mathrm{VIF}<10$ dan tolerance value $>0,1$. Kesimpulan dari hasil tersebut menunjukkan bahwa variabel indpenden yang digunakan dalam penelitian ini bebas dari multikolinearitas.

\subsection{Uji Heteroskedastisitas}

Tabel 3.2 Uji Heteroskedastisitas

\begin{tabular}{|c|c|c|c|c|c|c|}
\hline \multicolumn{7}{|c|}{ Coefficients ${ }^{a}$} \\
\hline & & \multicolumn{2}{|c|}{$\begin{array}{l}\text { Unstandardized } \\
\text { Coefficients }\end{array}$} & \multirow{2}{*}{$\begin{array}{c}\begin{array}{c}\text { Standardize } \\
d \\
\text { Coefficients }\end{array} \\
\text { Beta } \\
\end{array}$} & \multirow[b]{2}{*}{$\mathrm{t}$} & \multirow[b]{2}{*}{ Sig. } \\
\hline \multicolumn{2}{|c|}{ Model } & $B$ & Std. Error & & & \\
\hline \multirow[t]{4}{*}{1} & (Constant) & -2.463 & .393 & & -6.269 & .000 \\
\hline & intitusiona & & & -.042 & & .580 \\
\hline & manajerial & .012 & .077 & .012 & .153 & .879 \\
\hline & komisaris & 9.103 & .971 & .483 & 9.377 & .000 \\
\hline
\end{tabular}

Sumber: Hasil olah data

Berdasarkan tabel tersebut diketahui bahwa variabel kepemilikan institusional dan kepemilikan manajerial tidak terjadi gejala heteroskedastisitas, karena nilai signifikan $>0,05$ sedangkan variabel komisaris independen terjadi gejala heteroskedastisitas.

\subsection{Uji Autokorelasi}

Tabel 3.3 Uji Autokorelasi

\begin{tabular}{|l|c|r|r|r|r|}
\hline Model & $\mathrm{R}$ & $\begin{array}{c}\mathrm{R} \\
\text { Square }\end{array}$ & $\begin{array}{c}\text { Adjusted R } \\
\text { Square }\end{array}$ & $\begin{array}{r}\text { Std. Error of } \\
\text { the Estimate }\end{array}$ & $\begin{array}{r}\text { Durbin- } \\
\text { Watson }\end{array}$ \\
\hline 1 & $.343^{\mathrm{a}}$ & .117 & .108 & $\begin{array}{r}2.17516684 \\
18448\end{array}$ & 1.995 \\
\hline
\end{tabular}
a. Predictors: (Constant), komisaris. intitusional. manajerial
b. Dependent Variable: tobinsq

Sumber: Hasil olah data
Pada tabel Durbin Watson menunjukkan nilai dL sebesar 1,793 dan dU sebesar 1,821. Nilai Durbin Watson pada hasil penghitungan ternyata menunjukkan hasil yang lebih besar dari batas atas (dU) yakni 1,821 dan kurang dari (4-dU) atau sebesar 2,179. Dengan demikian, kesimpulan yang dapat diambil adalah tidak terjadi autokorelasi pada varian error dalam penelitian ini.

\subsection{Analisis Regresi Linear Berganda}

Tabel 3.4 Uji t



Sumber: Hasil olah data

a. Variabel kepemilikan institusional memiliki nilai thitung sebesar 0,247 dengan nilai signifikan 0,805. Dapat disimpulkan bahwa variabel ini tidak terdapat pengaruh signifikan terhadap Tobin's Q karena nilai signifikan $>0,05$.

b. Variabel komisaris independen memiliki nilai t hitung sebesar 6,184 dengan nilai signifikan 0,000. Dapat disimpulkan bahwa variabel ini berpengaruh signifikan terhadap Tobin's Q karena nilai signifikan $<0,05$.

c. Variabel kepemilikan manajerial memiliki nilai t hitung sebesar 0,177 dengan nilai signifikan 0,860. Dapat disimpulkan bahwa variabel ini tidak terdapat pengaruh signifikan terhadap Tobin's Q karena nilai signifikan $>0,05$.

\subsection{Pembahasan}

\subsubsection{Pengaruh Kepemilikan Institusional terha- dap Kinerja Pasar}

Hasil penelitian menunjukkan bahwa kepemilikan institusional tidak memiliki pengaruh 
signifikan terhadap kinerja pasar. Hal ini sesuai dengan penelitian Erkens, et al. (2012) yang menjelaskan bahwa dengan adannya nilai kepemilikan institusional yang tinggi justru akan memiliki risiko yang tinggi pula dan berimbas pada tingginya tingkat kerugian pemegang saham. Koladkiewicz (2002) menemukan bahwa kepemilikan institusional dapat mengurangi pengelolaan laba yang didapatkan oleh perusahaan. Ketika perusahaan tidak dapat mengelola laba dengan efisien, tingkat kepemilikan institusional yang tinggi justru akan mengurangi earning management.

Tingkat kepemilikan saham institusional yang tinggi tidak menjamin bahwa proses pengawasan dan monitoring akan berjalan dengan baik. Saat ini sudah banyak perusahaan yang menerapkan standar operasional perusahaan dengan baik. Hal ini dapat menjadi suatu perbaikan dalam meminimalisasi adanya tindak penyimpangan yang muncul.

\subsubsection{Pengaruh Komisaris Independen terhadap} Kinerja Pasar

Hasil penelitian menjelaskan bahwa komposisi komisaris independen berpengaruh positif terhadap kinerja pasar. Hasil ini sejalan dengan penelitian yang dilakukan Abbasi, et al. (2012) bahwa komisaris independen memiliki pengaruh signifikan terhadap kinerja pasar. Semakin besar proporsi komisaris independen maka semakin objektif keputusan yang diambil perusahaan untuk meningkatkan nilai perusahaan yang berdampak pada kinerja pasar. Dengan adanya komisaris independen dalam perusahaan maka diharapkan dapat membantu untuk melakukan pengawasan kinerja manajemen agar tidak terjadi adanya penyimpangan atau kecurangan dalam manajemen. Hal ini akan berdampak baik pada kinerja pasar.
Komisaris independen ini merupakan pihak eksternal yang bertugas untuk melakukan pengawasan dalam kinerja manajemen perusahaan. Terkadang komisaris independen ini juga menjadi investor bagi perusahaan. Dengan adanya komisaris independen ini diharapkan dapat menyatukan kepentingan pemegang saham minoritas dengan kepentingan manajemen. Kinerja komisaris independen yang efisien dan sesuai dengan tugas serta wewenangnya dapat memberikan tingkat kepercayaan dan rasa aman bagi investor lain yang menanamkan modal saham pada perusahaan.

\subsubsection{Pengaruh Kepemilikan Manajerial terhadap Kinerja Pasar}

Hasil penelitian menunjukkan tidak terdapat pengaruh antara kepemilikan manajerial dan kinerja pasar. Tingkat kepemilikan manajerial pada perusahaan di Indonesia masih sangat sedikit. Hal ini akan berdampak pada pengambilan keputusan dan kewenangan manajemen sangat rendah. Fama \& Jensen (1983) menjelaskan bahwa dalam keadaan tertentu, kepemilikan manajemen (insider) yang tinggi tidak selalu dapat berpengaruh terhadap nilai perusahaan yang berdampak pada kinerja pasar. Kepemilikan manajerial tidak dapat sepenuhnya dapat melakukan pengawasan seratus persen dalam kegiatan perusahaan.

Seperti halnya yang dijelaskan oleh Shleifer dan Vishny (1997) bahwa menurut teori keagenan, kepemilikan manajemen bagaikan pedang bermata dua yang dapat memengaruhi biaya keagenen. Kepemilikan manajemen dapat mengurangi biaya keagenen karena dengan adanya kepemilikan manajemen dalam perusahaan akan memberikan motivasi bagi manajemen untuk bertindak seperti pemegang saham. Akan tetapi di sisi lain, tingkat kepemilikan manajemen yang tinggi dapat menyebabkan salah pelaporan keuangan dan pengambilalihan saham minoritas. 
Berdasarkan hasil analisis tersebut, kepemilikan manajemen tidak terlalu berpengaruh bagi investor dalam menentukan perusahaan mana yang akan diinvestasikan. Investor lebih memilih untuk mempertimbangkan faktor lain dalam pemilihan investasi seperti misalnya kinerja keuangan perusahaan.

\section{KESIMPULAN}

Berdasarkan hasil analisis tersebut, dapat disimpulkan bahwa: Variabel kepemilikan institusional tidak berpengaruh signifikan terhadap kinerja pasar emiten yang terdaftar di Indeks Saham Syariah Indonesia tahun 2016 hingga 2018. Hal ini dikarenakan dengan tingginya tingkat kepemilikan institusional tidak menjamin bahwa proses pengawasan akan berjalan dengan efektif. Variabel komisaris independen berpengaruh signifikan positif terhadap kinerja pasar emiten yang terdaftar di Indeks Saham Syariah Indonesia tahun 2016 hingga 2018. Hal ini dikarenakan semakin besar proporsi komisaris independen dalam perusahaan akan menyebabkan pemilihan keputusan menjadi semakin objektif untuk meningkatkan nilai perusahaan dan berdampak pada kinerja pasar. Variabel kepemilikan manajerial tidak berpengaruh signifikan terhadap kinerja pasar emiten yang terdaftar di Indeks Saham Syariah Indonesia tahun 2016 hingga 2018. Hal ini disebabkan karena kepemilikan manajerial pada perusahaan di Indonesia memiliki jumlah yang sangat kecil sehingga tidak terlalu berdampak pada keputusan yang diambil oleh manajemen perusahaan. Variabel kepemilikan institusional, komisaris independen, dan kepemilikan manajerial secara simultan memiliki pengaruh signifikan terhadap kinerja pasar emiten yang terdaftar di Indeks Saham Syariah Indonesia tahun 2016 hingga 2018.

\section{DAFTAR RUJUKAN}

Abbasi, Majid, et al. 2012. Impact of Corporate Governance Mechanisms on Firm Value Evidence from the Food Industry of Iran. Journal of Basic and Applied Scientific Research, Vol 2(5), Hal. 4712-4721.

Alghifari, et al. 2013. Effect of Return on Assets (ROA) Against Tobin's Q: Studies in Food and Beverage Company in Indonesia Stock Exchange Years 2007-2011. International Journal of Science and Research (IJSR), Vol. 2 (1), Hal. 722-725.

Cho, M.H. 1998. Ownership Structure, Investment and the Corporate Value: An Empirical Analysis. Journal of Financial Economics, Vol. 47, Hal. 103-121.

Chung, K.H., J. Elder, \& J. Kim. 2009. Corporate Governance and Liquidity. Journal of Financial and Quantitative Analysis, forthcoming.

CNN Indonesia. 2017. OJK: Praktik GCG Perusahaan Indonesia Masih Tertinggal. Diunduh tanggal 21 Agustus 2019.

Debali, A. et al. 2017. Do Ownership Structure and Quality of Financial Information Affect The Cost of Debt of Tunisian Listing Firms? International Journal of Critical Accounting.

Hidayat, Athalia Ariati \& Sidharta Utama. 2015. Board Characteristics and Firm Performance: Evidence from Indonesia. International Research Journal of Business Studies. Vol. 8, No. 3. Hal. 137-154.

Jensen, M. \& Meckling. 1976. Theory of the Firm: Managerial Behavior, Agency Cost and Ownership Structure. Journal of Financial Economics, Hal. 305-360.

Jusoh, et al. 2014. Managerial Ownership and Market-Based Performance Indicators: Extended Agency Theory. Journal of Con- 
temporary Issues and Thought, Vol. 14, Hal. 8-19.

Koladkiewicz, Izabella. 2002. The Institutional Shareholders-Best Practice: The National Funds Experience. Journal Compilation, Vol. 10, Ha.l 187-192. Blackwell Publishing.

Komite Nasional Kebijakan Governance. 2011. Pedoman Umum Good Governance Bisnis Syariah.

Leung, S. dan B. Horwitz. 2007. Is Concentrated Management Ownership Value Increasing or Decreasing? Evidence in Hongkong, China during the Asian Financial Crisis. SSRN Working Paper Series, No. 984403.

Ruan, W. et al. 2011. Managerial Ownership, Capital Structure and Firm Value: Evi- dence from China's Civilian-run Firms. Australasian Accounting, Bussiness and Finance Journal, Vol. 5(3), Hal. 73-92.

Scjmid, M.M. \& Zimmermann H. 2007. Managerial Incentives and Firm Valuation Evidence from Switzerland. SSRN Working Paper Series, No. 78418.

Shleifer, A. \& R.W., Vishny. 1997. A Survey of Corporate Governance. A Journal of Finance, Vol. 52, Hal. 737-783.

Solomon, Jill \& Aris Solomon. 2004. Corporate Governance and Accountability. England: John Wiley \& Sons, Ltd.

Thanatawee, Yordying. 2014. Institutional Ownership and Firm Value in Thailand. Asian Journal of Business and Accounting, 7(2), Hal. 1-22. 